\title{
Pembelajaran Toilet Training dalam Melatih Kemandirian Anak
}

\author{
${\text { Muhammad Khoiruzzadi }{ }^{1} \text {, Nur Fajriyah }}^{2}$
}

Received: 20122019 / Accepted: 2312 2019 / Published online: 28122019

(C) 2019 Early Chilhood Islamic Education Study Program

Abstrak: Toilet training is one way that teachers can do in the development of children's independence. This study aims to describe the implementation of toilet training in exercising independence in children aged 2-3 years. This research is a field research with descriptive qualitative approach. The source of the data was taken from the results of the class teacher and school principal interviews as well as the observations of the students playing the Al-Ikhlas class aged 2-3 years at the Ulul Albab Integrated Islamic Palace Kraton Pekalongan City. The results of the study show the purpose of toilet training is to train children's independence in toileting, to introduce early on unclean objects, to identify items in the toilet and to properly teach urinating and defecating. The implementation of toilet training starts with planning, that is preparing story material from story books on the themes of activities in the toilet, the implementation is carried out by the teacher using the habituation method and the method of storytelling, and evaluating that the teacher assigns tasks to the child in the form of direct practice about activities related with toilet training.

\section{Keywords: Toilet Training, Independence}

\begin{abstract}
Abstrak: Toilet training merupakan salah satu cara yang bisa dilakukan guru dalam perkembangan kemandirian anak. Penelitian ini bertujuan untuk mendeskripsikan pelaksanaan toilet training dalam melatih kemandirian pada anak kelompok bermain usia 2-3 tahun. Penelitian ini merupakan penelitian lapangan dengan pendekatan kualitatif deskripstif. Sumber data diambil dari hasil wawancara guru kelas dan kepala sekolah serta hasil observasi siswa kelompok bermain kelas Al-Ikhlas usia 2-3 tahun di PAUD Islam Terpadu Ulul Albab Kraton Kota Pekalongan. Hasil penelitian menunujukkan tujuan dari toilet training adalah melatih kemandirian anak dalam bertoilet, mengenalkan sejak dini tentang najis, mengenali barang-barang yang terdapat di toilet dan mengajarkan BAK dan BAB secara benar. Pelaksanaan toilet training dimulai dengan perencanaan yaitu menyiapkan bahan cerita dari buku cerita tentang tema-tema kegiatan yang ada di toilet, pelaksanaan dilakukan guru dengan menggunakan metode pembiasaan dan metode bercerita, dan evaluasi yaitu guru memberikan tugas kepada anak berupa praktek secara langsung tentang kegiatan yang berkaitan dengan toilet training.
\end{abstract}

Kata Kunci: Toilet Training, Kemandirian

\footnotetext{
${ }^{1}$ UIN Sunan Kalijaga Yogyakarta

${ }^{2}$ IAIN Pekalongan
} 


\section{PENDAHULUAN}

Usia toddler merupakan periode usia 12 sampai 36 bulan. Masa ini adalah masa eksplorasi lingkungan dimana anak berusaha mencari tahu semua yang terjadi dan bagaimana mengontrol orang lain melalui perilaku temperamen, negativisme dan keras kepala (Musfiroh \& Wisudaningtyas, 2014, h. 159). Pada usia tersebut, fase kehidupan yang unik, dan berada pada masa proses perubahan berupa pertumbuhan, perkembangan, pematangan dan penyempurnaan, baik pada aspek jasmani maupun rohaninya yang berlangsung seumur hidup, bertahap dan berkesinambungan (Mulyasa, 2012, h. 16). Maka dari itu, banyak dari kalangan orang tua yang menyekolahkan anaknya pada Pendidikan Anak Usia Dini (PAUD). Dalam Undang-undang Republik Indonesia, Nomor 20 Tahun 2003, Bab I, Pasal I, butir 14 menyatakan bahwa, PAUD merupakan pendidikan yang paling mendasar dan menempati kedudukan sebagai golden age dan sangat strategis dalam pengembangan sumber daya manusia.

Pada anak usia toddler mengalami tiga fase yaitu : fase autonomi (anak dapat mengambil inisiatif sendiri dan mampu melakukan semuanya sendiri, namun lebih pada menunjukkan keinginannya sendiri menolak sesuatu yang tidak dikehendaki dan mencoba sesuatu yang diinginkan), fase anal (anak memasuki masa toilet training), dan fase praoperasional (anak mulai mampu membuat penilaian sederhana terhadap objek dan kejadian di sekitarnya (Musfiroh \& Wisudaningtyas, 2014, h. 159). Salah satu hal yang menjadi perhatian orang tua dan guru adalah kemandirian anak dalam ber-toilet, sehingga diperlukan toilet training baik oleh orang tua di rumah maupun guru di sekolah.

Toilet training pada anak usia toddler merupakan usaha untuk melatih anak agar mampu mengontrol melakukan buang air kecil dan buang air besar. Toilet training secara umum dapat dilaksanakan pada setiap anak yang sudah mulai memasuki fase kemandirian pada anak (Keen, 2007, h. 292; Wald, 2009, h. 295). Kemandirian harus dilatih dan dikembangkan pada anak sedini mungkin agar tidak menghambat tugas-tugas perkembangan anak selanjutnya (Yamin \& Sanan, 2010, h. 94). Erikson mengatakan bahwa masa kritis bagi perkembangan kemandirian berlangsung pada usia dua sampai tiga tahun (usia toddler). Pada usia ini tugas pekembangan anak adalah untuk mengembangkan kemandirian. Kebutuhan untuk mengembangkan kemandirian yang tidak terpenuhi pada usia sekitar dua sampai tiga tahun akan menimbulkan terhambatnya perkembangan kemandirian yang maksimal (Dhamayanti \& Yuniarti, 2006, h. 18).

Peran orang tua di rumah dan peran guru di sekolah sangat menentukan kemandirian anak dalam melakukan aktivitasnya di toilet (Anggraeni, 2017, h. 45; Rahayu \& Firdaus, 2015, h. 68; Salahudin, Pebrianti, \& Maulana, 2018, h. 59). Pengetahuan orang tua untuk mengajarkan toilet training pada anaknya akan berdampak besar terhadap kemandirian anak (Bukhari, Rahmatika, Hartaty, \& Iskandar, 2017, h. 86; Istianah, Indanah, \& Farida, 2014, h. 28). Demikian pula halnya dengan guru dalam melatih kemandirian anak melalui toilet training. Maka dari itu, orang tua dan guru dapat bekerja sama untuk membantu anak dalam mengembangkan kepribadian dan kemandirian anak (Dhamayanti \& Yuniarti, 2006, hlm. 19). Dalam mendapatkan pengetahuan tentang toilet training yang baik dan benar, orang tua dan guru perlu mencari informasi tersebut baik melalui buku bacaan atau modul panduan tentang toilet training (Iryanti \& Kamsatun, 2016, h. 34; Wijaya, Bangsa, \& Christianna, 2015, h. 1), dan dari orang lain seperti program penyuluhan dari ahlinya seperti bidan (Musfiroh \& Wisudaningtyas, 2014, h. 157).

Beberapa ahli berpendapat toilet training efektif bisa diajarkan pada anak usia mulai dari 24 bulan sampai dengan 3 tahun, karena anak usia 24 bulan memiliki 
kecakapan bahasa untuk mengerti dan berkomunikasi. Dalam melakukan pelatihan buang air kecil dan besar pada anak membutuhkan persiapan baik secara fisik, psikologis maupun secara intelektual melalui persiapan tersebut diharapkan anak mampu mengontrol buang air besar dan buang air kecil (Yektiningsih \& Infanteri, 2016, hlm. 47). Untuk mendapatkan hasil yang maksimal dalam toilet training khususnya mengenai kemandirian anak, setidaknya ada beberapa faktor yang perlu diperhatikan dalam mempengaruhi kemandirian anak yaitu lingkungan, pola asuh dari orang tua dan pendidikan (Santrock, 2003, h. 145-146).

Perlunya kerja sama antara orang yang bertanggung jawab terhadap kemandirian anak dalam toilet training baik di rumah maupun di sekolah. Pendidikan merupakan salah satu faktor dalam mengembangkan kemandirian anak. Guru menjadi pembimbing sekaligus contoh bagi anak yang berusia toddler. Belajar menggunakan toilet tidak bisa dilakukan sampai anak mampu dan ingin. Anak harus belajar mengenali kebutuhan tersebut, belajar menahan air besar atau kecil sampai dia berhasil melakukannya sendiridi toilet tanpa bantuan orang lain. Kebanyakan anak usia toddler belum siap, baik secara fisiologis yaitu kemampuan mengendalikan perkemihan dan pencernaan (Rahayuningsih \& Rizki, 2012, h. 274). Guru perlu melakukan pembiasaan secara berkesinambungan sampai anak benar-benar mampu mandiri (Iswantiningtyas \& Raharjo, 2016, h. 62; Silranti \& Yaswinda, 2019, h. 39) dalam melakukan aktivitasnya di toilet. Selain itu perlakuan guru yang positif terhadap anak juga menjadi kesuksesan dalam membuat anak menjadi mandiri (Anggraeni, 2017, hlm. 45). Kemandirian merupakan suatu keadaan dimana seseorang dapat mengusahakan dan berbuat sesuatu atas kesadaran dan usaha sendiri, dan ia tidak mudah menggantungkan diri kepada orang lain (Siswanto, Kholidah, \& Minarti, 2010, hlm. 195).

PAUD Islam Terpadu Ulul Albab Kraton Kota Pekalongan memiliki pembelajaran toilet training yang berbeda dengan lembaga lain. Jika lembaga lain kegiatan toilet training dianggap hal biasa, namun di PAUD Islam Terpadu Ulul Albab Kraton Kota Pekalongan ini dijadikan sebagai suatu pembelajaran, tentang bagaimana cara melakukan toilet training dengan baik dan benar. Jumlah peserta didik di PAUD Islam Terpadu Ulul Albab Kraton Kota Pekalongan saat ini adalah sebanyak 65 anak yang terbagi dalam 2 kelompok usia yaitu 2-3 tahun dan 3-4 tahun. Semua itu terbagi dalam 4 kelas yang setiap kelasnya diberikan nama-nama yang diambil dari Surat al-Qur'an, yaitu al-Ikhlas, al-Falaq, al-Ashr, al-Kautsar. Fokus dari penelitian penulis hanya pada anak yang berusia 2-3 tahun yang merupakan usia toddler di mana anak baru memasuki awal sekolah di PAUD Islam Terpadu Ulul Albab Kraton Kota Pekalongan.

Tujuan penelitian ini adalah untuk mengetahui tujuan dari pembelajaran toilet training, untuk mengetahui pelaksanaan toilet training pada kelompok bermain usia 2-3 tahun (Al-Ikhlas) di PAUD Islam Terpadu Ulul Albab Kraton Kota Pekalongan baik dari perencanaan, pelaksanaan maupun evaluasi dalam pembelajarannya, serta faktor yang menjadi pendukung dan penghambar dalam pembelajaran toilet training.

\section{METODE}

Pada Dalam penelitian ini termasuk dalam penelitian lapangan (field research). Pendekatan yang digunakan adalah pendekatan kualitatif deskriptif, yaitu prosedur penelitian yang menghasilkan data deskriptif berupa kata-kata tertulis atau lisan dari orang-orang dan perilaku yang dapat diamati, dengan sumber datanya yang terdiri dari data primer dan data sekunder. Untuk data primer adalah data yang diperoleh dari hasil 
wawancara dengan guru kelas kelompok Al-Ikhlas dan kepala sekolah, serta hasil observasi pembelajaran pada siswa kelompok Al-Ikhlas usia 2-3 tahun yang terbagi 7 laki-laki dan 5 perempuan PAUD Islam Terpadu Ulul Albab Kraton Kota Pekalongan. Sedangkan data sekunder diperoleh dari dokumentasi baik berupa teks maupun dokumen lain yang terkait dengan fokus penelitian di PAUD Islam Terpadu Ulul Albab Kraton Kota Pekalongan.

Setelah data tersebut terkumpul, langkah selanjutnya adalah menganalasisnya. Langkah peneliti dalam menganalisis data tersebut dimulai dengan menelaah seluruh data yang telah terkumpul. Data tersebut tentunya sangat banyak, setelah dibaca dan dipelajari, maka langkah berikutnya adalah melibatkan tiga komponen analisis, yaitu: reduksi data, penyajian data, dan penarikan kesimpulan.

Tabel.1 Data Subjek Penelitian

\begin{tabular}{|c|c|c|c|}
\hline Nama & Usia & Jenis Kelamin & Jabatan/Posisi \\
\hline LS & 48 tahun & $\mathrm{P}$ & Kepala sekolah \\
\hline AR & 29 tahun & $\mathrm{P}$ & Guru Kelas Al-Ikhlas \\
\hline ARSA & 3,5 tahun & $\mathrm{L}$ & Siswa \\
\hline AYA & 3 tahun & $\mathrm{L}$ & Siswa \\
\hline AZR & 2,5 tahun & $\mathrm{L}$ & Siswa \\
\hline ASM & 3,5 tahun & $\mathrm{P}$ & Siswa \\
\hline AAF & 2,5 tahun & $\mathrm{P}$ & Siswa \\
\hline HSA & 3,5 tahun & $\mathrm{P}$ & Siswa \\
\hline HFU & 3 tahun & $\mathrm{P}$ & Siswa \\
\hline MHAS & 3,5 tahun & $\mathrm{P}$ & Siswa \\
\hline MIN & 3,5 tahun & $\mathrm{L}$ & Siswa \\
\hline MR & 3 tahun & $\mathrm{L}$ & Siswa \\
\hline ER & 3 tahun & $\mathrm{L}$ & Siswa \\
\hline MPAH & 2,5 tahun & $\mathrm{L}$ & Siswa \\
\hline
\end{tabular}

\section{HASIL PENELITIAN DAN ANALISIS}

Bagaian Berdasarkan hasil penelitian baik secara observasi maupun wawancara, penulis setidaknya membagi dalam tiga tema yaitu kemandirian anak dalam toilet training, pembelajaran toilet training dan faktor yang menjadi pendukung dan penghambat dalam pelaksanaan toilet training.

\section{Kemandirian Anak dalam Toilet Training}

Anak yang berusia 2-3 tahun di PAUD Islam Terpadu Ulul Albab Kraton Kota Pekalongan merupakan tingkatan yang paling dasar. Selain diperkenalkan dan diajarkan tentang menggambar, mengaji, beribadah, berperilaku baik, menyanyi, menari dan lain sebagainya, anak juga mulai diajarkan ber-toilet dengan baik dan benar. Dari kedua belas anak, masih ada tiga anak yang kesulitan dalam toilet training yaitu AZR, AAF, dan MPH. Kesulitan yang dialami anak yaitu mengenai cara melepas celana bagi laki-laki dan rok bagi perempuan, ketakutan anak ketika masuk ke kamar mandi, ketidakmampuan anak dalam menggunakan gayung untuk menyiram air ke sumber najis ketika BAK, dan ketergantungan anak pada popok yang diberikan oleh orang tua. 
Rata-rata anak yang mengalami kesulitan dalam toilet training adalah anak-anak yang masih belum genap berumur 3 tahun. Di sini peran dari guru di sekolah dan orang tua di rumah menjadi kunci utama, selain itu perlunya kerjasama antara orang tua dan guru, jangan sampai guru di sekolah mengajarkan secara berkala, akan tetapi ketika di rumah, anak masih dibiasakan memakai popok. Orang tua perlu mengawasi, dan mengikuti arahan dari guru di sekolah ketika anak melakukan toilet training di rumah.

Di PAUD Islam Terpadu Ulul Albab Kraton Kota Pekalongan, anak yang belum bisa melakukan toilet training secara mandiri, guru memberikan tawaran kepada anak, apakah masih perlu dibantu secara penuh atau guru cukup mengawasi saja dan memberikan bantuan seperlunya. Sebagaimana penjelasan dari AR selaku guru kelas,

"di sini, kami para guru dalam mengajarkan toilet training kepada anak yang belum bisa mandiri dengan penuh adalah dengan memberikan tawaran kepada anak, apakah perlu dibantu atau tidak. Bagi anak yang menurut kami belum bisa mandiri, kami mengajarkan sedikit demi sedikit tentang toilet training. Selain itu, kami juga butuh persetujuan dari orang tua untuk mengajarkan toilet training di sekolah, dan juga perlu diterapkan atas pengawasan orang tua di rumah".

\section{Pembelajaran Toilet Training}

Pembelajaran toilet training pada kelompok bermain usia 2-3 tahun di PAUD Islam Terpadu Ulul Albab Kraton Kota Pekalongan memiliki tujuan, sebagaimana penuturan dari kepala sekolah (LS). Beliau menyatakan bahwa:

"Tujuan dari adanya pembelajaran toilet training sejak dini yaitu agar anak mampu melakukan BAB atau BAK sesuai pada tempatnya, selain itu untuk mengenalkan halhal yang terkait dengan najis. Selain menerapkan pembelajaran toilet training, kemandirian anak juga perlu untuk dikembangkan agar kedepannya anak mudah untuk menentukan pilihannya."

Dari hal tersebut, menunjukkan pentingnya pembelajaran toilet training sejak dini khususnya berkaitan dengan perkembangan anak usia 2-3 tahun. Selain itu untuk melatih kemandirian anak supaya bisa melakukan kegiatan-kegiatan yang ada di dalam toilet secara mandiri. Sebagaimana penuturan dari guru kelas (AR), beliau menyatakan bahwa, "Pelaksanaan toilet training ini supaya kemampuan anak dalam be-rtoilet training bisa dilakukan sejak dini, serta melatih kemandirian yang dimiliki oleh anak bisa berkembang sesuai dengan tahapan usia anak."

Kepala sekolah juga menambahkan mengenai salah satu tujuannya adalah melatih kemandirian sejak anak masuk ke PAUD Islam Terpadu Ulul Albab Kraton Kota Pekalongan, sebagaimana penuturan dari kepala sekolah (LS). Beliau menyatakan bahwa:

"Kegiatan atau pembelajaran toilet training yang dikenalkan sejak anak MOS serta sehari sekali diadakan pembelajaran toilet training sampai anak bisa untuk melakukan toilet training sesuai dengan prosedur yang diinginkan sekolah. Dengan adanya kemandirian-kemandirian yang diajarkan tersebut diharapkan anak mampu untuk melakukan suatu hal tanpa harus ada bantuan orang dewasa, yang bertujuan agar kemandirian anak bisa tumbuh sesuai dengan kemampuannya."

Berdasarkan hasil penelitian, pelaksanaan kegiatan belajar mengajar diawali dengan:

Pertama, perencanaan

Perencanaan dilakukan sehari sebelum kegiatan dilaksanakan berdasarkan tema, yang sebelumnya sudah dirancang mulai dari kegiatan untuk satu tahun, menentukan tema, membagi tema disetiap semesternya, memilih kegiatan untuk sub-sub tema sampai dengan program harian peserta didik. Kaitannya dengan pembelajaran toilet training, 
guru menyiapkan materi terlebih dahulu sebelum bercerita melalui media buku cerita yang berkaitan dengan toilet training.

Kedua, pelaksanaan

Berdasarkan hasil observasi di kelas Al-Ikhlas, setelah siswa melakukan kegiatan rutin mengaji, berbaris, senam dan lain sebagainya. Kemudian untuk kelompok AlIkhlas, setelah selesai kegiatan pemanasan dilanjut dengan kegiatan pijakan sebelum main yaitu diisi dengan memberikan waktu untuk minum dan tawaran anak untuk melakukan tawaran untuk pergi ke toilet, kemudian dilanjut dengan mengabsen anak menggunakan nanyian dan pertanyaan sederhana untuk melatih konsentrasi anak serta muroja'ah atau hafalan surat, dan hadist, setelah itu guru mulai memberikan cerita mengenai tema yang akan diajarkan pada anak dan memberikan kesempatan pada anak yang sudah dijadwalkan untuk ber-toilet training, penjadwalan tersebut dilakukan oleh tiga anak yang mana pembiasaan itu selalu dilakukan setiap harinya selama 1 bulan atau selama anak-anak masih belum dikatakan mandiri ketika BAB dan BAK. Untuk memberikan penjelasan tema kepada anak biasanya guru menggunakan buku-buku yang terkait dengan tema, serta media laptop untuk memberikan gambaran tema yang akan dibahas dan alat pendukung lainnya.

Untuk kegiatan toilet training, disampaikan melalui metode cerita, yang dibawakan oleh gurunya. Dengan menggunakan media buku cerita mengenai "cara melakukan buang air besar dan buang air kecil dengan benar", dalam cerita tersebut mengandung nilai mengenai buang air besar dan buang kecil itu dilakukan dengan yang benar seperti cara mengkomunikasikan secara verbal ketika hendak BAB atau BAK kepada ibu atau guru ketika di sekolah, cara melepas celana, cara jongkok dengan benar saat memakai tempat kloset, cara menguyur air kecing atau kotoran, cara membersihkan alat kelaminnya, setelah itu cara mencuci tangan yang benar usai memakai toilet dan memakai celana dengan benar.

Adapun alasan kenapa menggunakan metode bercerita yaitu menurut penuturan dari guru kelas (AR), menyatakan bahwa "metode bercerita yang digunakan untuk kegiatan toilet training itu bertujuan agar anak paham dengan apa yang dimaksudkan oleh guru mengenai pembelajaran toilet training yang akan anak lakukan, dan anak akan tertarik dengan buku yang digunakan oleh guru".

Penggunaan metode pembiasaan juga dipandang sebagai alternatif terbaik, supaya anak mengingat dan mau mengulang kembali di esok harinya. Sebagaimana penuturan dari guru kelas (AR), beliau menyatakan bahwa: " penggunaan metode pembiasaan itu merupakan metode yang sangat membantu anak untuk menginggat apa yang telah anak lakukan pada hari itu, kemudian akan terulang keesokan harinya dan seterusnya sampai anak itu hafal dengan sendirinya".

Selain menggunakan metode bercerita dan pembiasaan, anak juga diajarkan secara langsung (praktek) yaitu guru memberikan arahan pada anak untuk ber-toilet training secara langsung di kamar mandi. Arahan yang dilakukan guru ketika di kamar mandi yaitu:

a) Guru menunjukkan beberapa benda yang ada di kamar mandi dan menjelaskan kegunaannya, seperti sabun, air, bak mandi, gayung, dan sebagainya.

b) Kemudian guru membagi dua kelompok antara laki-laki dan perempuan.

c) Kemudian memberikan penjelasan kepada anak cara membuka celana untuk lakilaki dan perempuan. 
d) Selanjutnya guru memberikan penjelasan pada anak yang sedang BAK bagaimana cara menguyur air setelah selesai BAK dan menjelaskan cara mencuci di bagian organ yang mengelurkan kotoran tersebut.

e) Setelah itu, guru mengarahkan anak untuk cuci tangan dan cuci kaki, agar kotorannya hilang.

f) Guru juga memberikan penjelasan mengenai najis ketika bagian anggota tubuh terkena BAK dan BAB, maka hal yang harus dilakukan adalah mecuci sampai kotoran itu benar-benar sudah hilang.

g) Dan setelah selesai, guru mengajarkan cara memakai celana. Ketiga, evaluasi

PAUD Islam Terpadu Ulul Albab menggunakan peneliaian evaluasi yakni pemberian tugas; pemberian tugas dapat bersifat mandiri atau kelompok. Kaitannya dengan pembelajaran toilet training, anak diberi tugas untuk mengenali barang-barang yang ada di toilet dan praktek secara langsung tentang buang air kecil dan cuci tangan yang benar. Catatan anekdot; PAUD Islam Terpadu Ulul Albab juga menggunakan catatan anekdot dalam penilaian perkembangan siswa, dimana catatan ini mengenai kejadian atau peristiwa yang berkaitan dengan kegiatan-kegiatan yang ada di toilet. Adapun catatan tambahan yaitu lembar penilaian dan jurnal sentra.

\section{Faktor Pendukung dan Penghambat}

Adapun yang menjadi faktor pendukung pembelajaran toiliet training dalam melatih kemandirian anak usia 2-3 tahun di PAUD Islam Terpadu Ulul Albab Kota Pekalongan diantaranya kerjasama antara guru dan orang tua atau wali murid, usia kesiapan anak, dan sarana prasana yang memadai dalam pembelajaran toilet training. Hal ini menjadi poin penting dalam keberhasilan anak bisa mandiri khususnya dalam berkegiatan toilet training. Seperti yang diungkapkan oleh kepala sekolah (LS), beliau menyatakan bahwa,

"yang menjadi faktor pendukung dari adanya pelaksanaan pembelajaran toilet training dilembaga ini adalah: Pertama, adanya kerja sama antara orang tua wali murid dengan pihak sekolah atau kesepakatan bersama dengan adanya pembelajaran tersebut. Kedua, usia kesiapan anak berpengaruh terhadap kemampuannya untuk menerima pembelajaran toilet training yang diterapkan. Ketiga, sarana dan prasarana yang terpenuhi sangat berpengaruh terhadap kemampuan anak dalam bertoilet training.dan yang keempat, kemampuan guru dalam memberikan pembelajaran toilet training pada anak harus sesuai dengan kriteria yang telah ditetapkan disekolah".

Hal senada juga diungkapan oleh AR selaku guru kelas kelompok Al-Ikhlas, juga berpendapat mengenai faktor faktor pendukung pembelajran toilet training dalam melatih kemandirian anak, beliau menambahkan bahwa pembiasaan secara terus menerus juga menjadi hal penting dalam keberhasilan kemandirian anak dalam toilet training.

"Pertama, kerjasama antara orang tua dengan sekolah harus sejalan, karena dengan adanya kerja sama tersebut, orang tua akan mengimbangi anak untuk belajar toilet training dirumah sendiri sesuai dengan yang diajarkan di sekolah. Kedua, kemampuan anak dalam bertoilet training atau usia anak, kemampuan dan usia anak sangat berpengaruh terhadap kondisi anak dalam menerima informasi mengenai toilet training, sehingga benar-benar membutuhkan kemampuan dan usia anak yang tergolong memiliki usia yang matang atau usia yang cukup untuk menerima pembelajaran toilet training yaitu usia yang sudah memasuki 2 tahun. Ketiga, kondisi dari sarana dan prasarana yang memadahi, karena sarana dan prasarana di sekolah sangat berpengaruh terhadap 
pembelajaran toilet training anak, selain itu untuk memberikan kondisi atau gambaran yang nyata bagi anak bahwa ketika melakukan toilet training itu terdapat kamar mandi berserta alat-alat kamar mandi yang lengkap. Keempat, pembiasaan yang terus diilakukan, pembiasaan yang terus menerus dilakukan bertujuan agar anak mudah untuk melakukan toilet training, serta agar anak mudah untuk mengingat".

Sedangkan yang menjadi faktor penghambat dalam pembelajaran toilet training adalah usia dari anak yang belum matang untuk melakukan toilet training, dan orang tua yang masih ketergantungan dalam penggunaan popok pada anak. Sebagaimana yang diungkapkan oleh LS dan AR,

"Faktor penghambatnya yaitu: pertama, kesiapan anak yang belum matang untuk melakukan toilet training disekolah. kedua, ketidak sesuaian orang tua terhadap pihak sekolah yang telah memberikan pembelajaran toilet training (orang tua yang bergantung pada penggunaan pempers pada anak)".

\section{PEMBAHASAN}

\section{Usia dan Pengarahan dari Guru Berperan Penting dalam Kemandirian Anak}

Beberapa ciri-ciri dari kemandirian anak yang berusia 2-3 tahun (toddler) adalah mencuci muka, menyisir rambut, sikat gigi, dan anak mampu menggunakan toilet (Kartono dalam Anggraeni, 2017, h. 33). Dari hal tersebut, maka tidak salah PAUD Islam Terpadu Ulul Albab Kraton Kota Pekalongan menerapkan pembelajaran toilet training pada siswanya. Tujuan dilakukannya pembelajaran toilet training pada kelompok bermain usia 2-3 tahun di PAUD Islam Terpadu Ulul Albab Kraton Kota Pekalongan adalah untuk mengenalkan sejak dini tentang najis, mengenali barang-barang yang terdapat di toilet, mengajarkan $\mathrm{BAK}$ dan $\mathrm{BAB}$ secara benar, dan untuk melatih kemandirian anak dalam bertoilet. Pada usia ini merupakan periode emas sekaligus merupakan periode kritis bagi anak dimana perkembangannya yang didapatkan pada periode ini sangat berpengaruh terhadap perkembangan pada periode berikutnya hingga masa dewasanya (Kurniasih, 2009, h. 11). Salah satu yang menjadi perhatiannya adalah aspek dari kemandirian anak.

Menurut Piaget, pada usia 2-3 tahun secara perkembangan kognitif anak masuk pada tahap praoperasional (early childhood), perubahan paling jelas yang terjadi adalah peningkatan luar biasa dalam aktivitas representasi atau simbolis (Kurniasih, 2009, h. 11). Pada tahap ini konsep yang stabil dibentuk, penalaran muncul, egosentris mulai kuat dan kemudian mulai melemah, serta terbentuknya keyakinan terhadap hal yang magis (Piaget dalam Ibda, 2015, h. 32). Dalam istilah pra-operasional menunjukkan bahwa pada tahap ini teori Piaget difokuskan pada keterbatasan pemikiran anak. Istilah "operasional" menunjukkan pada aktifitas mental yang memungkinkan anak untuk memikirkan peristiwa pengalaman yang dialaminya (Jahja, 2011, h. 185).

Kemandirian dalam bertoilet harus mulai diperkenalkan kepada anak sedini mungkin. Dengan menanamkan kemandirian akan menghindarkan anak dari sifat ketergantungan pada orang lain, dan yang terpenting dalam menumbuhkan keberanian anak dilakukan dengan memberikan motivasi pada anak untuk terus mengetahui pengetahuan-pengetahuan baru melalui pengawasan baik orang tua di rumah maupun guru di sekolah. Ada dua bentuk kemandirian anak yaitu kemandirian secara fisik da secara psikologis (Nurfalah, 2010, h. 13). Secara fisik, anak mampu mengurus dirinya sendiri seperti contoh sederhana dalam ber-toilet, BAK, BAB, berwudhu, dan mandi. 
Sedangkan secara psikologis yaitu anak berani untuk toilet training secara mandiri, dan anak tidak segan untuk meminta pertolongan kepada guru di sekolah saat toilet training.

Kemandirian pada anak-anak terlihat ketika anak menggunakan pikirannya sendiri dalam mengambil berbagai keputusan, tumbuhnya kemandirian pada anak-anak bersamaan dengan munculnya rasa takut (kekhawatiran) dalam berbagai bentuk dan intensitasnya yang berbeda-beda. Rasa takut dalam hal yang wajar dapat berfungsi sebagai "emosi pelindung diri" (protetive emotion) bagi anak-anak, yang memungkinkannya mengetahui kapan waktunya meminta perlindungan kepada orang dewasa atau orang tuanya (Susanto, 2017, h. 35). Aspek yang menjadi poin penting dalam hal ini adalah umur dari anak, idealnya anak yang memasuki usia 2-3 tahun, anak sudah mulai diajarkan toilet training secara mandiri.

Untuk melatih kemandirian anak dalam bertoilet, selain menyediakan kesempatan yang sesuai dengan umur anak juga perlu menyediakan bantuan hanya jika mereka minta. Kadang anak minta bantuan ketika mereka sebenarnya hanya minta ditemani atau diperhatikan (McDevitt \& Ormrod, 2002, h. 439). Anak perlu didorong untuk melakukan sesuatu sendiri yang mereka dapat lakukan. Kemudian guru perlu menahan diri untuk menunggu anak memakai celana, menaikkan resleting, mengerti kapan anak perlu dibantu tanpa diambil alih, tidak berbicara terlalu banyak saat anak sedang berusaha belajar bertoilet. Membangun kompetensi pada diri anak dengan membiarkan anak melakukannya sendiri, akan meningkatkan harga diri yang selanjutnya dapat melatih pengendalian diri anak (Hendrick, 1996, h. 18).

\section{Implementasi Toilet Training}

Toilet training merupakan upaya pelatihan kontrol BAK dan BAB anak yang masing-masing dilakukan oleh sistem perkemihan dan defekasi Seorang anak dikatakan sedang menjalani toilet training bila ia diajarkan untuk datang ke toilet saat ingin BAK atau $\mathrm{BAB}$, membuka pakaian seperlunya, melakukan miksi dan defekasi, membersihkan kembali dirinya, dan memakai kembali pakaian yang dilepaskannya. Guru perlu mengawasi dan memberikan arahan yang benar kepada anak ketika anak melakukan toilet training.

Toilet training di PAUD Islam Terpadu Ulul Albab Kraton Kota Pekalongan ini dijadikan sebagai suatu pembelajaran, tentang bagaimana cara melakukan toilet training dengan baik dan benar sehingga harapannya adalah melatih kemandirian anak dalam BAK, BAB, mencuci tangan, membuka dan memakai pakaian seperlunya, serta yang lainnya. Dalam pelaksanaan toilet training, dilakukan mulai dari kegiatan penyambutan siswa, kemudian mengajak anak untuk membaca qiroati di pagi hari sebelum berbaris, setelah membaca qiroati anak bersiap untuk berbaris bersama, setelah berbaris, anak diberi waktu untuk minum susu dan melakukan toilet training, selanjutnya kegiatan do'a sebelum belajar dan bernyanyi sesuai dengan tema, kegiatan hari ini, kemudian evaluasi atau penutup.

Pada tahap perencanaan, guru memproyeksikan tindakan apa yang akan dilaksanakan dalam suatu pembelajaran dengan mengatur dan menetapkan komponenkomponen pengajaran, sehingga tujuan isi materi, metode dan teknik, serta evaluasi menjadi jelas dan sistematis (Suryana, 2016, h. 218). Perencanaan dalam pembelajaran harus dipenuhi oleh guru sebelum ia mengajar. Guru memulai dengan pembuatan RPP (rencana pelaksanaan pembelajaran) untuk satu tahun (PROTA), kemudian rencana pelaksanaan pembelajaran untuk yang satu semester, dilanjut dengan pembutan RPPM (rencana pelaksanaan pembelajaran mingguan), sampai dengan RPPH (rencana pelaksanaan pembelajaran harian). Dimulai dari penyambutan peserta didik, kegiatan 
qiroati sebelum masuk kelas, berbaris bersama, kegiatan inti sampai dengan waktu pulang dan evaluasi.

Pada tahap pelaksanaan, pembelajaran toilet training yang dilakukan guru melalui metode pembiasaan dan metode bercerita pada anak usia 2-3 tahun secara rutin. Metode pembiasaan digunakan agar anak tidak cepat lupa dan diusahakan untuk membiasakan pembelajaran-pembelajaran dalam bertoilet yang baik dan benar (Iswantiningtyas \& Raharjo, 2016, h. 62; Silranti \& Yaswinda, 2019, h. 39). Menurut Pavlov dari pembiasaan yang dilakukan oleh anak, juga diperlukan penguatan berupa pengulangan-pengulangan (Soekamto \& Winaputra, 1997, h. 37) dari toilet training tersebut.

Selain itu, anak berperilaku dalam kemandirian bertoilet juga berdasarkan pengamatan secara langsung sehingga menurut Bandura dilakukan proses peniruan (imitation) dan konsep percontohan (modelling) (Suryono \& Haryanto, 2012, h. 88). Jadi di sini peran guru sangat urgen dalam menjelaskan apa saja yang perlu dilakukan anak ketika dia mau BAK, BAB, berwudhu, mandi, dan lain sebagainya yang berkaitan dengan kegiatan-kegiatan yang ada di toilet. Guru menjadi contoh dan memberikan rangsangan kepada anak, agar anak meniru apa yang sesuai guru lakukan dalam ber-toilet. Selain itu, guru perlu memotivasi anak agar anak tetap semangat dalam mengikuti toilet training.

Hal yang menarik adalah dengan bercerita kepada anak tentang toilet training. Hal ini sangat efektif dilakukan guru, karena anak pada usia 2-3 tahun lebih tertarik dengan cerita-cerita yang menarik ditambah dengan gambar-gambar yang ada (Silranti \& Yaswinda, 2019, h. 39). Sehingga anak akan jauh lebih antusias dalam mengikuti toilet training. Secara perkembangan kognitif anak pada usia 2-3 tahun masuk dalam tahapan operasional (Berk, 2012, h. 30). Dan salah satu ciri anak pada usia 2-3 tahun adalah perceptually bound yaitu anak menilai sesuatu apa yang dilihat atau yang didengar. Selain itu juga centration, yaitu anak memusatkan perhatiannya kepada sesuatu ciri yang paling menarik menurut anak tersebut (Ibda, 2015, h. 32-33).

Pada tahap evaluasi, guru memberikan tugas kepada anak berupa praktek secara langsung tentang kegiatan yang berkaitan dengan toilet training. Anak tidak hanya diberi penjelasan saja mengenai ber-toilet yang baik dan benar, namun anak langsung diberi tugas berupa praktek. Guru juga mengamati dan menilai bagaimana anak mencuci tangan, buang air kecil, mencopot dan memakai celana bagi laki-laki dan rok bagi perempuan, cara membenarkan resleting, menyiram air bekas najis yang benar, membersihkan bagian yang terkena najis dengan air secara benar. Dari pemberian tugas secara praktek langsung, guru akan mengetahui perkembangan anak dalam ber-toilet. Selain itu, akan penugasan secara langsung dengan praktek akan mengembangkan kemandirian anak (Rochwidowati \& Widyana, 2016, h. 63; Silranti \& Yaswinda, 2019, h. 60) Instrumen penilaian yang digunakan catatan anekdot, lembar penilaian, dan jurnal sentra.

\section{SIMPULAN DAN SARAN}

Tujuan dari toilet training di PAUD Islam Terpadu Ulul Albab Kraton Kota Pekalongan adalah untuk melatih kemandirian anak dalam bertoilet, untuk mengenalkan sejak dini tentang najis, mengenali barang-barang yang terdapat di toilet dan mengajarkan BAK dan BAB secara benar. Pelaksanaan toilet training di PAUD Islam Terpadu Ulul Albab Kraton Kota Pekalongan dimulai dengan tahap perencanaan yaitu menyiapkan bahan cerita dari buku cerita tentang tema-tema kegiatan yang ada di toilet, tahap pelaksanaan dilakukan guru dengan menggunakan metode pembiasaan dan metode bercerita pada anak usia 2-3 tahun secara rutin tentang tema-tema ber-toilet, tahap 
evaluasi yaitu guru memberikan tugas kepada anak berupa praktek secara langsung tentang kegiatan yang berkaitan dengan toilet training.

Faktor yang mendukung dalam pembelajaran toilet training adalah kesiapan dari siswa, kerjasama antara guru dan orang tua, sarana dan prasana, dan pembiasaan yang dilakukan setiap hari kepada anak dalam pelaksanaan toilet training. Sedangkan faktor yang menjadi penghambat adalah usia yang terlalu dini dan ketidaksinkronan antara ketika anak di sekolah dan ketika anak di rumah dalam toilet training, dan pembiasaan pemakaian popok pada anak sehingga anak menjadi ketergantungan pada popok.

Saran bagi orang tua, ketika anak hendak mencoba toilet training secara mandiri, orang tua tidak perlu takut terlalu berlebihan sehingga anak akan belajar sedikit demi sedikit dalam toilet training. Ketika orang tua takut pada anak yang melakukan toilet training secara mandiri, setidaknya dilakukan pengawasan, pengarahan dan menolong anak ketika membutuhkan pertolongan dalam toilet training. Over protektif dari orang tua kepada anak juga menjadi kendala anak dalam mengembangkan kemandiriannya dalam toilet training.

\section{AKNOWLEDGMENT}

Pekalongan.

Peneleitian ini di dukung oleh UIN Sunan Kalijaga Yogyakarta dan IAIN

\section{DAFTAR RUJUKAN}

Anggraeni, A. (2017). kompetensi Kepribadian Guru Membentuk Kemandirian Anak Usia Dini. AWLADY : Jurnal Pendidikan Anak, 3(2), 28-47.

Berk, L. E. (2012). Development Through The Lifespan. Yogyakarta: Pustaka Pelajar.

Bukhari, Rahmatika, L., Hartaty, N., \& Iskandar. (2017). Hubungan Pengetahuan Orang Tua Tentang Toilet Training Pada Anak Usia 18-36 Bulan Dengan Pelaksanaannya di Desa Gue Gajah Kecamatan Darul Imarah. Jurnal Aceh Medika, 1(1), 86-94.

Dhamayanti, A. A., \& Yuniarti, K. W. (2006). Kemandirian Anak Usia 2,5-4 Tahun Ditinjau dari Tipe Keluarga dan Tipe Sekolah. Jurnal Sosiosains, 19(1), 17-29.

Hendrick, J. (1996). The Whole Child. New Jersey: Marrill Prentice Hall.

Ibda, F. (2015). Perkembangan Kognitif. Jurnal Inetelektualita, 3(1), 27-38.

Iryanti, \& Kamsatun. (2016). Pengaruh Modul Pemberdayaan Keluarga tentang Toilet Training terhadap Kemandirian Eliminasi Anak di PAUD. Jurnal Keperawatan Padjadjaran, 4(1), 34-44. https://doi.org/10.24198/jkp.v4i1.135

Istianah, Indanah, \& Farida, U. (2014). Pengetahuan Ibu Meningkatkan Kemampuan "Toilet Training" Anak. Jurnal Keperawatan Anak, 2(1), 28-33.

Iswantiningtyas, V., \& Raharjo, I. B. (2016). Kemandirian Anak Usia Dini ( Studi di Taman Kanak-kanak Tauladan Kecamatan Pare Kabupaten Kediri ). SELING: Jurnal Program Studi PGRA, 2(1), 59-62. https://doi.org/10.29062/seling.v2i1.217

Jahja, Y. (2011). Psikologi Perkembangan. Jakarta: Kencana.

Keen, D. (2007). Toilet Training for Children with Autism: The Effects of Video Modeling. Journal of Developmental and Physical Disabilities, 19(4), 291-303.

Kurniasih, I. (2009). Pendidikan Anak Usia Dini. Jakarta: Edukasia. 
McDevitt, T. M., \& Ormrod, J. E. (2002). Child Development and Education. New Jersey: Merrill Prentice Hall, Pearson Education.

Mulyasa. (2012). Manajemen Paud. Bandung: PT Remaja Rosdakarya.

Musfiroh, M., \& Wisudaningtyas, B. L. (2014). Penyuluhan Terhadap Sikap Ibu dalam Memberikan Toilet Training pada Anak. Jurnal Kesehatan Masyarakat, 9(2), 157-166.

Nurfalah, Y. (2010). Panduan Praktis Melatih Kemandirian Anak Usia Dini. Bandung: PNFI Jayagiri.

Rahayu, D. M., \& Firdaus. (2015). Hubungan Peran Orang tua dengan Kemampuan Toilet Training pada Anak Usia Toddler di PAUD Permata Bunda RW 01 Desa Jati Selatan 1 Sidoarjo. Jurnal Ilmiah Kesehatan, 8(1), 68-75.

Rahayuningsih, S. I., \& Rizki, M. (2012). Kesiapan Anak dan Keberhasilan Toilet Training di Paud dan TK Bungong Seuleupoek Unsyiah Aceh. Idea Nursing Journal, III(3), 274-284.

Rochwidowati, N. S., \& Widyana, R. (2016). Peningkatan Kemandirian Anak Usia Prasekolah dengan Pemberian Pengukuh Positif. InSight, XIII(1), 49-65.

Salahudin, I., Pebrianti, S., \& Maulana, I. (2018). Hubungan Pengetahuan dengan Sikap Ibu dalam Penerapan Toilet Training pada Anak Usia Toodler di Desa Majasari Garut. Jurnal Publikasi Kesehatan Masyarakat, 5(2), 59-64. http://dx.doi.org/10.20527/jpkmi.v5i2.5484

Santrock, J. W. (2003). Adolesence Perkembangan Remaja. Jakarta: Erlangga.

Silranti, M., \& Yaswinda. (2019). Pengembangan Kemandirian Anak Usia 5-6 Tahun di TK Dharmawanita Tunas Harapan. Jurnal Caksana: Pendidikan Anak Usia Dini, 2(1), 39-48. https://doi.org/10.31326/jcpaud.v2i1.367

Siswanto, W., Kholidah, L. N., \& Minarti, S. U. (2010). Membentuk Kecerdasan Spiritual Anak: Pedoman Penting Bagi Orang Tua dalam Mendidik Anak. Jakarta: Amzah.

Soekamto, T., \& Winaputra, U. S. (1997). Teori Belajar Dan Model-Model Pembelajaran. Jakarta: Dikti.

Suryana, D. (2016). Pendidikan Anak Usia Dini Stimulasi dan Aspek Perkembangan Anak. Jakarta: Kencana.

Suryono, \& Haryanto. (2012). Belajar Dan Pembelajaran Teori Dan Konsep Dasar. Bandung: Remaja Rosdakarya.

Susanto, A. (2017). Pendidikan Anak Usia Dini. Jakarta: Bumi Aksara.

Wald, E. R. (2009). Bowel Habits and Toilet training in a Diverse Population of Children. Journal of Pediatric Gastroenterology \& Nutrition, 48(3), 294-298.

Wijaya, D. G., Bangsa, P. G., \& Christianna, A. (2015). Perancangan Buku Interaktif Tentang Toilet Training Anak Usia 1-3 Tahun. Jurnal DKV Adiwarna, 1(6), 1-12.

Yamin, M., \& Sanan, J. S. (2010). Panduan Pendidikan Anak Usia Dini. Ciputat: Gaung Persada Group.

Yektiningsih, E., \& Infanteri, W. F. (2016). Pengetahun Ibu Tentang Penerapan Toilet Training pada Anak Usia 2-3 Tahun di Posyandu Anggrek Desa Lamongan Kecamatan Badas Kabupaten Kediri. Jurnal AKP, 7(2), 46-51. 


\section{AUTHOR}

Muhammad Khoiruzzadi UIN Sunan Kalijaga Yogyakarta dan Nur Fajriyah IAIN Pekalongan. 